\title{
Impacts of Ozone on Trees and Crops
}

${ }^{1}$ Benjamin S. Felzer, ${ }^{1}$ Timothy Cronin, ${ }^{2}$ John M. Reilly, ${ }^{1}$ Jerry M. Melillo, ${ }^{2}$ Xiaodong Wang,

${ }^{1}$ The Ecosystems Center, Marine Biological Laboratory, 7 MBL St., Woods Hole, MA 02543, U.S.A., (508) 2897748 (phone), (508) 4571548 (fax), bfelzer@mbl.edu

${ }^{2}$ Joint Program on the Science and Policy of Global Change, Massachusetts Institute of Technology, 77 Massachusetts Ave., Cambridge, MA 02139, U.S.A.

In this review article, we explore how surface-level ozone affects trees and crops with special emphasis on consequences for productivity and carbon sequestration. Vegetation exposure to ozone reduces photosynthesis, growth, and other plant functions. Ozone formation in the atmosphere is a product of NOx that are also a source of nitrogen deposition. Reduced carbon sequestration of temperate forests resulting from ozone is likely offset by increased carbon sequestration from nitrogen fertilization. However, since fertilized croplands are generally not nitrogen-limited, capping ozone-polluting substances in the U.S., Europe, and China can reduce future crop yield loss substantially.

Keywords: ozone, nitrogen deposition, vegetation, photosynthesis, stomatal conductance, crop yield, carbon storage 


\section{$\underline{\text { Introduction }}$}

Changes in land use and the chemical composition of both the atmosphere (increased $\mathrm{CO}_{2}$ and $\mathrm{O}_{3}$ concentrations) and precipitation (increased nitrogen concentrations) during the last century have directly affected biogeochemical cycling of vegetation and soils. Increased atmospheric $\mathrm{CO}_{2}$ levels and changing land-use patterns, such as conversion of land to agriculture, have also indirectly affected the biota through changes in climate. Besides positive $\mathrm{CO}_{2}$ and nitrogen fertilization effects and direct consequences of landuse change, air pollutants have had a significantly negative effect on vegetation productivity and crop yield since the latter half of the $20^{\text {th }}$ century. Over $90 \%$ of vegetation damage may be the result of tropospheric ozone alone (Adams et al. 1986). In this article, we provide reviews of a) ozone formation and related air-quality issues, b) ozone affects on plants, c) modeling studies that explore the effects of ozone on vegetation, d) regional-scale consequences of ozone and nitrogen deposition on vegetation and crop responses using biogeochemical and atmospheric chemistry models, and f) future consequences of ozone on crop yield, carbon storage and the economy.

\section{$\underline{\text { Ozone formation and air quality issues }}$}

Tropospheric ozone production is the result of photochemical reactions of carbon monoxide $(\mathrm{CO})$, methane $\left(\mathrm{CH}_{4}\right)$, and other hydrocarbons in the presence of $\mathrm{NOx}(\mathrm{NO}+$ $\mathrm{NO}_{2}$ ). Net reactions include (Schlesinger 1991):

(1) $\quad \mathrm{NO}_{2}+\mathrm{O}_{2} \leftrightarrow \mathrm{NO}+\mathrm{O}_{3}$

(2) $\mathrm{CO}+2 \mathrm{O}_{2} \rightarrow \mathrm{CO}_{2}+\mathrm{O}_{3}$

(3) $\mathrm{CH}_{4}+4 \mathrm{O}_{2} \rightarrow \mathrm{HCHO}+\mathrm{H}_{2} \mathrm{O}+2 \mathrm{O}_{3}$ 
(both 2 and 3 depend upon reactions with $\mathrm{OH}$ and with $\mathrm{NOx}$ as they occur in 1). Ozone destruction is also the result of photochemical reactions, involving $\mathrm{NO}, \mathrm{HO}_{2}$, or $\mathrm{OH}$. NOx is primarily a product of fossil fuel combustion (63\%), but is secondarily a result of biomass burning (14\%), lightning (10\%), soils (11\%), and other small sources (IPCC 2001). Hydrocarbons are also the result of fossil fuel emissions, as well as direct evaporation of fuel, solvent use, chemical manufacturing, and natural vegetation (Mauzerall and Wang 2001). Natural vegetation is a source of volatile organic compounds (VOCs), which decompose into peroxy radicals $\left(\mathrm{RO}_{2}\right.$ where $\mathrm{R}$ is an organic radical), which react with $\mathrm{NO}$ to produce $\mathrm{NO}_{2}$ (Krupa and Manning 1988). In urban regions with high concentrations of NOx, ozone production is generally VOC-limited, whereas in suburban or rural regions with low NOx levels, ozone production is NOxlimited. Ozone is also transported into a region by local winds and downward from the stratosphere (Oltmans and Levy II 1994). The different spatial distributions of NOx and VOC production, as well as NO destruction of ozone, often result in the largest ozone concentrations downwind of urban centers, rather than in urban areas themselves (Mauzerall and Wang 2001, Gregg et al. 2003).

Ozone production occurs during times of high temperature and solar radiation, such as during stagnant high pressure systems in summer (Mauzerall and Wang 2001). Whereas natural ozone production is expected to reach a maximum in early spring (Singh et al. 1978), current maxima often occur during summer due to increased NOx and VOC emissions (Mauzerall and Wang 2001). Industrial continental regions tend to have maximum ozone values in the late afternoon and minimum values in the early morning 
hours. In contrast, marine and high latitude sites have maximum ozone values before sunrise and lowest values in the afternoon due to low NOx concentrations and therefore low ozone production and strong ozone destruction (Oltmans and Levy II 1994). Background ozone levels in unpolluted air can be anywhere from 20-50 ppb (Seinfeld 1989), though Lefohn et al. (2001) argued for occasional background levels over $60 \mathrm{ppb}$ resulting from stratospheric input. Polluted regions can have ozone levels peaking as high as $400 \mathrm{ppb}$ (Seinfeld 1989).

Nitrogen deposition $(\mathrm{NOy}+\mathrm{NHx})$ resulting from nitrogen oxides emitted during fuel combustion and ammonia volatized from agricultural processes have increased the inputs of nitrate $\left(\mathrm{NO}_{3}\right)$ and ammonium $\left(\mathrm{NH}_{4}\right)$ to forest ecosystems (Melillo and Gosz 1983, Nadelhoffer et al. 1999). NOy is NOx plus the compounds produced from the oxidation of $\mathrm{NO}_{\mathrm{x}}$, such as nitric acid $\left(\mathrm{HNO}_{3}\right)$ and peroxyacetyl nitrate (PAN). The NOx responsible for over half the total N-deposition (Melillo and Steudler 1989) is also responsible for the formation of ozone. There is only a small coupling between ozone and $\mathrm{NHx}$, due to the gas-phase oxidation of $\mathrm{NH} 3$ by $\mathrm{OH}$, which represents only about $5 \%$ of the total loss of NHx (D. Lucas, personal communication). While a primary effect of NOx is to increase soil fertility, it also has negative effects on vegetation due to acid rain and loss of stomatal control by direct absorption into leaves (Mansfield et al. 1993, Teskey 1996). In an experiment on crops, Runeckles and Palmer (1987) found that daily treatments of $\mathrm{O}_{3}$ following $\mathrm{NO}_{2}$ resulted in larger growth inhibitions than ozone alone for radish and wheat, yet the reverse effect for bush bean. In all cases, $\mathrm{NO}_{2}$ alone increased growth. 


\section{Effects of ozone on vegetation}

The effects of ozone on vegetation have been studied in both the laboratory and in field experiments, using controlled greenhouses or growth chambers, open-top chambers (OTCs), or field plots (Krupa and Manning 1988). We focus on trees and crops because most studies have involved these growth forms (MacKenzie and El-Ashry 1989). The majority of experiments have applied ozone to seedlings in growth chambers (e.g. Pye 1988, Lyons et al. 1997, Zheng et al. 1998). The most recent results come from Free Air $\mathrm{CO}_{2}$ Enrichment (FACE) experiments that show the interaction of elevated ozone and $\mathrm{CO}_{2}$ (Long et al. 2005, 2006, Leakey et al. 2006). We review visible injury to plants exposed to ozone, the physiological effects of ozone on vegetation, growth responses of plants, mechanisms of ozone response, and the interaction of ozone and $\mathrm{CO}_{2}$. To the extent ozone reduces growth, it affects the amount of carbon in vegetation and soils, and the harvestable portions of crops. The review is summarized in Table 1.

\section{Visible Injury and Physiological Effects}

Visible injury resulting from chronic exposure to low ozone concentrations includes changes in pigmentation or bronzing, chlorosis, and premature senescence after chronic exposure to low ozone concentrations. Flecking and stippling may occur after acute exposure to high ozone levels (Krupa and Manning 1988). For some tree species, such as yellow poplar (Somers et al. 1998), loblolly pine (McLaughlin and Downing 1995, 1996), and white pine (Bartholomay et al. 1997), there is a correlation between visible injury and reductions in growth, while in many studies for a wide-range of species, 
including some of the above, there does not appear to be a correlation (Reich and Amundson 1985, Pye 1988, Chappelka and Samuelson 1998).

Physiological effects of ozone exposure include reduced photosynthesis, increased turnover of antioxidant systems (Percy et al. 2003), damage to reproductive processes (Chappelka 2002), increased dark respiration (Grulke and Miller 1994, Tjoelker et al. 1995), lowered carbon transport to roots (Cooley and Manning 1987), reduced decomposition of early successional communities (Kim et al. 1998), and reduced forage quality of C4 grasses (Muntifering et al. 2000, Powell et al. 2003). Response to ozone appears to vary considerably among species. Results for red spruce showed no change in photosynthesis with elevated ozone (Chappelka and Samuelson 1998). Reich and Amundson (1985) found a 50\% reduction in photosynthesis for crops such as clover and wheat, but only a $10 \%$ reduction for white pine. Results vary even within the same species: Some studies of loblolly pine have shown reductions in photosynthesis while other studies have shown no effect. Using a linear model to summarize about 20 OTC experiments each for conifers, hardwoods, and crops, Reich (1987) postulated that an ozone dose of $20 \mathrm{ppm}$-hr results in a photosynthesis reduction of $7 \%$ for conifers, $36 \%$ for hardwoods, and $73 \%$ for crops.

\section{Growth Responses}

Reduced photosynthesis results in decreased growth rates, which are often measured as either volume or biomass. Reich (1987) determined that the reduction in photosynthesis describe above resulted in a growth reduction of $3 \%$ for conifers, $13 \%$ for hardwoods, 
and $30 \%$ for crops. In contrast to the Reich and Amundson (1985) linear model, Percy et al. (2007) recently have used the aspen FACE data to show that the growth response of aspen trees to ozone more closely resembles a non-linear cubic regression. Pye (1988) documented a wide-range of negative biomass responses of different species to elevated ozone, with the largest being a $69 \%$ decrease. The Southern Oxidant Study concluded that ozone had led to a 1-25\% growth reduction in eastern U.S. forests (Heck and Furiness 2001), while Chappelka and Samuelson (1998) reported growth reductions of 010\% per year. The Southern Appalachian Mountains Initiative concluded that black cherry and yellow poplar were the most sensitive to ozone, while red maple, loblolly pine, and northern red oak were intermediate, and red spruce the most tolerant (Heck and Furiness 2001). Synthesizing the growth reductions of loblolly pine in the southeast U.S., the Southern Commercial Forest Research Cooperative concluded that ozone was responsible for a 2-5\% annual growth reduction (Teskey 1996). The Mid-Atlantic Integrated Assessment (Heck and Furiness 2001) concluded that the biomass of black cherry decreased by $27 \%$, yellow poplar by $16 \%$, and loblolly pine by $1 \%$.

Many studies have detailed the reduction of crop yield and photosynthesis by exposure to ozone (Fiscus et al. 2005). The National Crop Loss Assessment Network (NCLAN) program set out to study the effects of ozone on crop yield using open-top chambers throughout the U.S. (Heck et al. 1984a,b, Heck 1989), while a European OTC program (EOTCP) provided a similar study in Europe (Fuhrer et al. 1997). While EOTCP focused on processes and critical levels of ozone effects on crops, NCLAN focused on providing dose-response functions for economic assessments (Spash 1997). NCLAN results 
indicate a reduced annual soybean yield of $10 \%$ and a reduced cotton yield of $12 \%$ for seasonal mean ozone levels greater than $50 \mathrm{ppb}$ (Heagle 1989), and a substantial economic benefit of $\$ 0.7$ billion for a 10\% ozone reduction (Adams et al. 1986). Corn and other monocots appeared to be less sensitive, while results with winter wheat were highly variable (Heagle 1989). For a range of studies on spring wheat, Fuhrer et al. (1997) modeled a reduction of yield with increasing ozone over a $40 \mathrm{ppb}$ threshold, resulting in a $10 \%$ reduction in yield for ozone levels commonly found in southern Europe. Westenbarger and Frisvold (1995) modeled a $0.3 \%$ to $0.9 \%$ increase in corn and soybean yield, respectively, in the eastern U.S. with a $20 \mathrm{ppm}-\mathrm{hr}$ summer ozone exposure standard. Spash (1997) synthesize a wide-range of economic assessments of ozone damage to crops. In addition, they emphasize the need to consider the demand response resulting from reductions in crop quality as well as the supply response resulting from reductions in crop yield. In the Reich (1987) study discussed above, he concluded that crops were the most sensitive and conifers the least (with hardwoods intermediate) to ozone, since crops have the highest conductances and conifers the lowest. However, the lifetime effects on leaves or needles were similar or even reversed due to the longer lifespan of vegetation with lower conductivity (Reich 1987). Furthermore, Pye (1988) suggested that the high hardwood sensitivity in the Reich (1987) model may have been to the overabundance of poplar in the sample set.

\section{Mechanisms of Ozone Response}

Ozone uptake is a function of both ambient ozone levels and stomatal conductance (Mauzerall and Wang 2001). Ozone affects vegetation by direct cellular damage 
(especially to palisade mesophyll cells) once it enters the leaf through the stomates. Gaseous $\mathrm{O}_{3}$ diffuses from the atmosphere, through the stomata, and dissolves in water surrounding the cells before entering the cells themselves (Mauzerall and Wang 2001). The cellular damage is probably the result of changes in membrane permeabilities and may or may not result in visible injury or reduced growth or yield (Krupa and Manning 1988). Stomata generally open in response to light and warmth and close in response to aridity, water stress, and high $\mathrm{CO}_{2}$ (Mauzerall and Wang 2001). A secondary response to ozone is a reduction in stomatal conductance, as the stomata close in response to increased internal $\mathrm{CO}_{2}$ that occurs because of the reduced photosynthetic activity caused by the ozone (Reich and Amundson 1985, Reich 1987, Runeckles and Chevone 1992). It has been suggested that the decrease in stomatal conductance caused by $\mathrm{O}_{3}$ is similar in magnitude to the $10 \%$ decrease caused by $\mathrm{CO}_{2}$ increases since preindustrial conditions (Taylor et al. 1994). Tjoelker et al. (1995) found a decoupling between photosynthesis and stomatal conductance as a result of long-term ozone exposure. Generally, the stomatal control of ozone uptake provides a coupling between environmental conditions and ozone uptake as well as a potential negative feedback to ozone uptake itself. Not all ozone enters the leaves through the stomata. A smaller amount of ozone can enter leaves by direct absorption along leaf exterior surfaces (Pleijel et al. 2004).

Ozone uptake depends strongly on stomatal conductance, which varies with climatic and atmospheric conditions. While ozone may reduce stomatal conductance somewhat, it generally increases water stress by reducing root growth (McLaughlin and Downing 1995, 1996). Many studies have noted less ozone damage under drought conditions 
because of the dependence on stomatal conductance (Showman 1991, Runeckles and Chevone 1992, Smith et al. 2003). Beyers et al. (1992) and Pell et al. (1993) used OTCs to determine the interacting effects of $\mathrm{O}_{3}$ and soil moisture on radish and ponderosa pine seedlings, respectively. For example, Beyers et al. (1992) found a biomass reduction of $19.5 \%$ for well-watered seedlings vs. $11 \%$ for drought-stressed seedlings when exposed to 1.5 times ambient ozone levels. Results of these experiments showed that ozone damage to biomass was less with reduced soil moisture due to stomatal controls. However, other studies (McLaughlin and Downing 1995, 1996, Bartholomay et al. 1997) showed that plants exhibited more ozone sensitivity under moisture-stress conditions. Experiments with 3 year old beech trees in growth chambers have shown that while ozone may decrease stomatal conductance under moist conditions, it may actually increase stomatal conductance under drought stress (Mansfield et al. 1993). Jensen and Roberts (1986) also showed higher ozone sensitivity under more humid atmospheric conditions due to higher stomatal conductance. Under future conditions of higher $\mathrm{CO}_{2}$ fertilization, it is possible that ozone damage will be reduced due to lower stomatal conductance (Grulke and Miller 1994, Fiscus et al. 2005).

Besides stomatal controls, plant defense mechanisms also regulate the effective ozone uptake, which is defined as the difference between the stomatal ozone uptake and the defensive response (Musselman and Massman 1999, Massman 2004). Detoxification by chemical reactions occurs from both existing antioxidants and those stimulated by ozone itself. Emissions of NO within leaves also help to destroy ozone. Because antioxidants are produced from photosynthates, lower levels of antioxidants at night may lead to 
greater sensitivity to ozone at that time (Musselman and Massman 1999). Also, as ozone levels early in the day deplete antioxidant supplies, plants may be subject to more effective ozone uptake later in the day when ozone levels are normally highest (Musselman and Massman 1999, Massman 2004). In addition to defense by chemical reactions, repair of injured tissue and alteration of metabolic pathways occurs in response to ozone (Musselman and Massman 1999). Teskey (1996) notes that while stomatal regulation may limit ozone uptake, by also limiting photosynthesis, it also reduces the availability of plant repair mechanisms.

The effects of ozone on seedlings are not generally representative of the effects on mature trees or forest ecosystems (Chappelka and Samuelson 1998) and (Taylor et al. 1994)). McLaughlin and Downing (1995, 1996), studying a mature stand of loblolly pines under natural climatic and ozone conditions, determined a $27-50 \%$ reduction in stem growth, largely attributed to ozone exposure. Bartholomay et al. (1997) showed strong negative correlations between ozone and radial growth for white pines in Acadia National Park. Tjoelker et al. (1995) found that shaded leaves were more sensitive than sun-lit leaves to ozone exposure in a mature stand of the shade-tolerant sugar maple. Most comparisons of seedlings vs. mature trees showed greater ozone sensitivity in seedlings, including red spruce (Rebbeck and Jensen 1993), sequoias (Grulke and Miller 1994), and black cherry (Fredericksen et al. 1996). Greater ozone sensitivity in seedlings was attributed to larger stomatal conductances in all of these cases. Since leaf area increases more rapidly with age than does transpiration, leaf-specific transpiration rates, and thus stomatal conductances, generally decrease with age (Meinzer and Grantz 1991). Furthermore, 
older trees maintain larger hydraulic resistances due to more complex branching and longer vertical distances to the leaves, and this leads to lower leaf water potential and lower stomatal conductances (Chappelka and Samuelson 1998). Studies of red oak, however, show an enhanced sensitivity to ozone in 30 year old mature trees vs. 2 year old seedlings, due to higher stomatal conductances in the older trees (Samuelson and Edwards 1993, Edwards et al. 1994, Hanson et al. 1994). The larger stomatal conductance in mature red oak might be related to greater demand for carbohydrates (Samuelson and Kelly 1996) or higher concentrations of nitrogen in leaves and fine roots in the mature trees than seedlings (Samuelson et al. 1996). Both of these differences between mature trees and seedlings would imply greater photosynthetic rates in the older trees, leading to higher stomatal conductances. This study points to the difficulties of generalizing the age dependency of tree sensitivity to ozone.

There is also a potential adaptive response to ozone exposure (Treshow and Stewart 1973, Percy et al. 2003). Berrang et al. $(1986,1989,1991)$ showed that quaking aspen from more ozone polluted areas in the U.S. were less sensitive to ozone when exposed to high ozone levels in either greenhouses or different field environments. Karnosky and Steiner (1981) showed a similar response to green and white ash seedlings. These experiments implied that adaptation to high ozone levels occurred. A suggested mechanism was growth reduction leading to shading by faster-growing tolerant clones (Berrang et al. 1989). The more ozone-sensitive species also tended to have a higher genetic multiplicity and diversity (Percy et al. 2003). Indeed, Barbo et al. (1998) showed 
that in an early successional plant community, exposure to ozone led to a less complex community structure by affecting competitive interactions among plants.

\section{Ozone and $\mathrm{CO}_{2}$}

Increasing $\mathrm{CO}_{2}$ levels in the future might counteract some of the negative effects of ozone on vegetation growth and productivity. Several Aspen FACE experiments were designed to study such interactive effects. In the Aspen FACE study in northern Wisconsin (Karnosky et al. 2003, Karnosky et al. 2005) seedlings of aspen, birch, and maple were studied to determine the effects of $\mathrm{CO}_{2}$ (ambient vs. $560 \mathrm{ppm}$ ) and $\mathrm{O}_{3}$ (ambient vs. 1.5x ambient) together and independently on photosynthesis and growth. Karnosky et al. (2003) found that the elevated ozone levels completely offset the growth enhancements from the elevated $\mathrm{CO}_{2}$ concentrations. An interactive effect between $\mathrm{CO}_{2}$ and ozone might be expected as ozone uptake is reduced by the lower stomatal conductance at elevated $\mathrm{CO}_{2}$. Karnosky et al. (2005) showed that ozone reduced height and diameter growth of aspen in both ambient and elevated $\mathrm{CO}_{2}$ environments, but birch growth was reduced only in elevated $\mathrm{CO}_{2}$ (relative to elevated $\mathrm{CO}_{2}$ alone). Similarly, ozone exposure reduced maximum photosynthetic rates in aspen by $20 \%$ and $28 \%$, and in birch by $0 \%$ and $17 \%$, under ambient and elevated $\mathrm{CO}_{2}$, respectively. Sugar maple experienced no ozone effects until the fourth year of growth in both $\mathrm{CO}_{2}$ environments. These results do not support the hypothesis of reduction in ozone uptake due to stomatal closure at elevated $\mathrm{CO}_{2}$, and indicate a negative interactive effect between $\mathrm{CO}_{2}$ and ozone. Using these data, Kubiske et al. (2006) showed that interannual variability of 
climate mediated most of the aspen growth response to both $\mathrm{CO}_{2}$ and $\mathrm{O}_{3}$, with the environmental drivers of July radiation and October temperatures enhancing both effects.

The SoyFACE experiment at the University of Illinois at Urbana-Champaign has been established to look at the effects of $\mathrm{CO}_{2}$ and ozone on soybean. Slower senescence from elevated $\mathrm{CO}_{2}$ levels of 550 ppm was offset by accelerated senescence from elevated ozone levels at 23\% above ambient levels (Dermody et al. 2006). Morgan et al. (2006) found substantial decreases in above-ground net primary production (NPP) of $11 \%$ during 2002 and 23\% during 2003 as a result of the increased ozone levels during 20022003. However, Christ et al. (2006) found no significant ozone effects on crop yield in 2004, which they attributed to lack of drought stress and lower ambient ozone levels during 2004. This study suggests the importance of climatic conditions to the overall ozone effect. Long et al. (2005) use SoyFACE results to conclude that ozone damage to crops may outweigh any gains resulting from $\mathrm{CO}_{2}$ fertilization. They found yield increases of $15 \%$ for soybean under $\mathrm{CO}_{2}$ elevation to $\sim 560 \mathrm{ppm}$, comparable to the reduction in yield due to elevated ozone. Since no factorial analysis including $\mathrm{CO}_{2}$ and ozone together has yet been performed for a commercially important crop species under free-air conditions, much more experimental work remains to be done, and it must suffice for now to simply compare the magnitudes of the $\mathrm{CO}_{2}$ and ozone effects. An important factor in such a comparison is that the magnitude of ozone damage varies greatly with crop species; according to work by Long et al. (2005), maize and rice are much less susceptible to ozone than wheat and soybean. In terms of $\mathrm{CO}_{2}$ fertilization, species is less important than photosynthetic pathway; C4 crops likely have little to gain from elevated $\mathrm{CO}_{2}$ in the absence of water stress (Leakey et al. 2006), and although estimates 
of $\mathrm{C} 3$ crop gains from $\mathrm{CO}_{2}$ fertilization differ widely and are hotly disputed (Long et al. 2006, Tubiello et al. 2007), they are almost certainly non-negligible. The ozone and $\mathrm{CO}_{2}$ fertilization effects are thus clearly the same order of magnitude, but their relative magnitudes and interactive effects are still highly uncertain and dependent on both species and environmental conditions.

\section{Modeling ozone effects on plants}

Understanding the experimental results and extrapolating across large regions involves the use of numerical models. Modeling the effects of ozone on vegetation can involve simple regression analysis, plant-physiological models, or ecosystem-scale models. At the ecosystem scale, empirical relationships determine the effect of ozone on photosynthesis over the course of the growing season. The plant physiological models are able to make use of the diurnal cycle to determine more directly how ozone impedes the photosynthetic apparatus. In either case, some assumptions about how ozone affects photosynthesis or stomatal conductance are required. These ozone effects are often in the form of dose-response relationships developed from experimental data, and generally involve accumulated measures of ozone uptake.

Dose-response functions have been developed to quantify the effects of ozone on photosynthesis. Dose is the amount of $\mathrm{O}_{3}$ available during the response period and is defined as the $\mathrm{O}_{3}$ concentration multiplied by the duration of exposure (Krupa and Manning 1988). While doses measure the concentration over a period of time, because of antioxidant defenses, ozone is often observed to affect vegetation only after surpassing 
certain threshold levels (Massman 2004). Under low antioxidant conditions, plants may have a much lower ozone threshold (Reich and Amundson 1985, Weinstein et al. 1998). Different ozone indices that account for threshold effects include the AOT40, SUM06, and W126 indices. The AOT40 index is the sum of the amounts by which hourly ozone concentrations exceed a threshold of $40 \mathrm{ppb}$ over the growing season and during daylight hours. The SUM06 is the sum of the hourly ozone concentrations over $60 \mathrm{ppb}$ over the growing season and during daylight hours. The AOT40 index has commonly been used to define critical levels of ozone in Europe (Fuhrer et al. 1997), whereas the SUM06 index has commonly been used in the U.S., based upon crop yield studies. Although the threshold for SUM06 is higher, once it is reached, it accumulates more rapidly than AOT40 (Mauzerall and Wang 2001). The W126 index weights each hourly value by a sigmoidal weighting scheme, so that low ozone values are not completely ignored (Westenbarger and Frisvold 1995). Other non-threshold indices have been developed to provide a metric for human health in North America, such as the 3-year average of the annual fourth highest daily maximum 8-hour ozone concentrations, which Percy et al. $(2006,2007)$ have shown is highly correlated, along with environmental variables like wind speed and growing degree days, to Aspen growth at the Aspen FACE site in Rhinelander, WI. Flux-based dose-responses account for stomatal conductance to determine the ozone uptake, and may include a threshold such as the flux-based AOT40 used here or in the Ollinger et al. (1997) study. Pleijel et al. (2004) compared a number of these indices for wheat and potatoes and concluded that the threshold-based flux index best captured ozone damage to crop yield. 
Tree physiology models enable us to better understand the processes by which ozone affects plant photosynthetic apparatus and carbon allocation among different parts of the plant. These models are based on single trees and normally operate at the hourly time step, and therefore directly compute the effects of the diurnal ozone cycle (Constable and Friend 2000). These models can also account for carbon allocation among roots, stems, and leaves, thereby allowing for differential ozone effects on each of these plant parts. Such differential effects may be another explanation for the age-variant sensitivity to ozone; more mature trees may be able to offset some carbon loss in leaves by drawing from a larger pool of labile carbon (Constable and Friend 2000). The TREGRO model reduces mesophyll conductance to simulate the effects of ozone. The model has been used (Yun et al. 2001) to show that the effects of ozone on aspen are highly dependent upon external environmental conditions and can even be more sensitive with less ozone exposure under certain meteorological conditions. The effects of ozone on aspen were also studied using the tree physiological model ECOPHYS, which includes ozone effects on photosynthesis and stomatal conductance and explicitly accounts for the detoxifying effects of antioxidants by enabling ozone damage only when plant defenses are overwhelmed. Simulations with ECOPHYS (Martin et al. 2001) found that there were substantial differential effects on leaves, roots, and stems, with stem dry matter and diameter, leaf biomass and area, and root growth being most sensitive to ozone exposure. Combining the TREGRO model with the stand-level ZELIG model for loblolly pine and yellow-poplar, Laurence et al. (2001) showed that moderate ozone effects on individual trees may result in large effects at the stand-level, as the more ozone-sensitive species suffer competitive exclusion. 
It is possible to make more accurate estimates of ozone uptake by using eddy covariance data along with Soil-Vegetation- Atmosphere-Transfer (SVAT) models to determine the flux of ozone entering the leaves. The SVAT models are resistance-flow models that represent the exchange of fluxes between the atmosphere and surface by a resistornetwork analogue. While eddy covariance fluxes can provide the total flux into the canopy, the SVAT models are used to partition the fluxes between stomatal absorption, external surfaces, and the soil (Musselman and Massman 1999, Grunhage et al. 2000). Using these methods at a sitka spruce site in Scotland, Coe et al. (1995) found that rates of ozone uptake by vegetation at midday were up to three times higher than could be explained by stomatal considerations alone, which suggests the importance of a further mechanism for ozone removal, such as photochemical destruction at the leaf cuticles.

Ecosystem-scale models enable us to extrapolate effects on individual trees to entire ecosystems and regions to determine, for example, how ozone affects vegetation productivity on the continental-scale. In one of the early ecosystem-scale studies, Ollinger et al. (1997) used the PnET-II forest ecosystem model to study the effects of ozone on hardwoods at 64 sites in the northeastern U.S. for the late 1980s through the early 1990s. They found a reduction in net primary productivity (NPP) of between 3$16 \%$, with less of a reduction on drier sites due to lower stomatal conductance. Ollinger et al. (2002) later applied their ozone algorithms to a version of PnET (PnET-CN) that included $\mathrm{N}$ cycling to evaluate the interactive effects of $\mathrm{CO}_{2}, \mathrm{O}_{3}$, and $\mathrm{N}$ within a context of historic land use changes for the hardwoods at the same sites in the northeastern U.S. 
They found that ozone reduced forest growth and C storage, and so partially compensated for the stimulatory effects of $\mathrm{CO}_{2}$ fertilization and $\mathrm{N}$ deposition. Felzer et al. (2004) applied the Reich (1987) and Ollinger et al. (1997) models to conifers and crop to extrapolate across the conterminous U.S. In these extrapolations they found a 3-7\% decrease in NPP from 1989-1993 and a reduction in carbon sequestration from 18-38 Tg C $\mathrm{yr}^{-1}$ since the 1950s, with largest damage in the midwestern croplands. In a global analysis, Felzer et al. (2005) determined that the most severe ozone damage to vegetation occurred in three hotspots, the southeastern and midwestern U.S., eastern Europe, and eastern China. From that modeling study, Felzer et al. (2005) estimated that during 19891993 ozone decreased the NPP by 7.0\% in the U.S., 11.2\% in Europe, and 7.2\% in China. Chameides et al. (1999) used an atmospheric chemistry model along with a regional climate model to estimate that the yield of winter wheat in much of southeastern China may be suppressed by more that $10 \%$ due to high ozone levels. Wang and Mauzerall (2004) explored the effect of ozone on crop yields in 2020 for China, Japan, and South Korea and showed an $82 \%$ cost increase over 1990 for China. In another modeling study of crops in China, Aunan et al. (2000) concluded that management could take advantage of different crop sensitivities to ozone to reduce future crop loss.

Since nutrient availability plays a strong role in governing the productivity of many ecosystems, accurately modeling the effects of ozone on the carbon cycle requires some assumptions about the effects of ozone on nutrient cycling. Models that include Ncycling, for example, may simulate a shift towards less $\mathrm{N}$-limiting conditions if carbon uptake is lowered without also lowering $\mathrm{N}$ uptake. In a study involving trembling aspen 
and paper birch, Lindroth et al. (2001) found that $\mathrm{C}: \mathrm{N}$ was unaffected by ozone in aspen, but changes in birch, with the direction of change dependent on atmospheric $\mathrm{CO}_{2}$ concentration. Holmes et al. (2003), using data from the Aspen FACE, showed that elevated ozone decreased gross $\mathrm{N}$ mineralization and microbial biomass $\mathrm{N}$ through both limits to quantity of plant litter and changes to litter quality. Swank and Vose (1990) inferred reduced $\mathrm{N}$-uptake in pines exposed to high ozone levels, due to higher $\mathrm{NO}_{3}$ concentrations in runoff. Reducing the C:N may have the reverse effect by increasing decomposition and net $\mathrm{N}$ mineralization, allowing for more uptake by vegetation (Felzer et al. 2004).

\section{Ozone and Nitrogen Deposition in Forests}

We have developed new analyses to determine the interactive effects of ozone and nitrogen deposition at the regional scale, since any realistic assessment of the regional ozone damage to natural ecosystems should also consider the accompanying fertilization effects of nitrogen deposition. Using atmospheric chemistry models, we previously developed a global AOT40 map (Figure 1a) by combining the current-day Multiscale Atmospheric Transport and Chemistry (MATCH) model ozone distribution with zonal hourly data from the Massachusetts Institute of Technology (MIT) Integrated Global Systems Model (IGSM) (Felzer et al. 2005). Because the AOT40 is a threshold index, levels are zero in the early half of the $20^{\text {th }}$ century. Using the Model for Ozone and Related Chemical Tracers, version 2 (MOZART2) model (Lamarque et al. 2005), we have determined the NOy deposition due to anthropogenic factors by subtracting the preindustrial 1890 NOy from the 2000 levels (Figure 1b). Fossil fuel combustion is 
responsible for the $\mathrm{N}$ in $\mathrm{NOy}$, which is the same $\mathrm{N}$ that is responsible for much of the formation of $\mathrm{O}_{3}$. The mapped patterns show an overall similarity in the hotspots between the two pollutants, including the eastern U.S., Europe, and eastern China. In the U.S. and Europe, ozone levels are generally higher relative to NOy further south due to the photochemical predominance of ozone synthesis. Ozone has longer atmospheric residence times than $\mathrm{NOx}$, on the order of days to weeks rather than hours to a day (Schlesinger 1991), so atmospheric transport of ozone also accounts for some of the differences.

Assuming that most croplands are fertilized so that ozone damage will occur regardless of natural N-deposition levels, we asked whether or not the positive effects of NOy on carbon sequestration outweigh the negative effects of ozone in forested regions. Because boreal forests don't utilize $\mathrm{NO}_{3}$ as efficiently as temperate forests (Downs et al. 1993), we focused on temperate forests for this discussion. We used the Terrestrial Ecosystems Model (TEM version 4.3) to determine the ozone effects (Felzer et al. 2005) in temperate forested regions of the U.S., Europe, China, and the globe. Ozone exposure reduces carbon storage between 10-20 Tg C amongst the U.S., Europe, and China, and by $73 \mathrm{Tg}$ C globally in the 1980s and 1990s (Table 2).

We made stoichiometric assumptions to estimate the carbon sequestration rates due to NOy deposition (Melillo and Gosz 1983). For our high estimate we assumed 13\% of nitrogen goes into the woody biomass (Magill et al. 2000) with a $\mathrm{C}: \mathrm{N}$ of 500 (Nadelhoffer et al. 1999), and the remaining 87\% is distributed between soils and non- 
woody biomass with $\mathrm{C}: \mathrm{N}$ of 30 . These assumptions imply that one gram of nitrogen sequesters 91 grams of carbon at the ecosystem level. Nadelhoffer et al. (1999) found that $\mathrm{N}$ deposition has only a limited effect on carbon sequestration because they assumed that only $5 \%$ is taken up by woody biomass, with $70 \%$ of the nitrogen going into the soils, $15 \%$ going into non-woody biomass, and $10 \%$ leached from the system. For our low estimate we used their assumptions, but applied a lower C:N of 300 for the woody biomass (Melillo et al. 2002). This calculation implies that one gram of nitrogen sequesters 40 grams of carbon at the ecosystem level. Under the high estimate, NOy

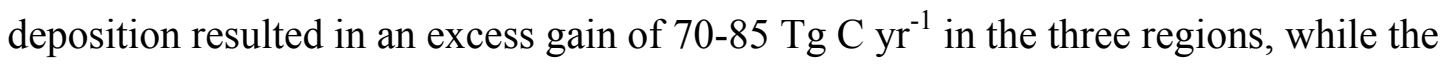

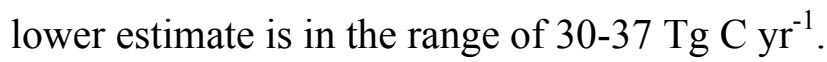

The results of this analysis show, that in all cases, the benefits of NOy deposition on carbon sequestration outweigh the negative effects of ozone on carbon sequestration in temperate forests. Therefore a complete carbon budget in non-managed ecosystems must consider the compensating effects of both ozone and NOy to provide an unbiased view of the net carbon storage. While the results of $\mathrm{N}$ deposition are usually positive, large levels of $\mathrm{N}$ deposition to pines at experimental sites in Harvard Forest have shown biomass reductions or even tree mortality, and similar consequences are likely in Europe as a result of high $\mathrm{N}$ deposition (Magill et al. 2000, 2004). In these cases, nitrogen doubly damages the ecosystem, by both toxically enriching the soil, and enhancing the production of ozone. 


\section{Modeling Future Effects of Ozone on Crop Yields, Carbon Storage, and the Economy}

In managed ecosystems such as croplands, however, where the sensitivity of specific crops to ozone is sometimes severe, reducing ozone levels can significantly increase crop yield and carbon sequestration. As these agricultural lands are often heavily fertilized, reducing ozone levels will have no negative effect of reduced nitrogen deposition. Pell et al. (1990) showed ozone damage to radish dry weight was negligible under low nitrogen conditions, but significant under high nitrogen.

Future effects of ozone depend on projections of economic activity, emissions of ozone precursors and other substances, and translation of impacts on vegetation to effects on yields and carbon storage. The consequent economic effects can then be valued in terms of impact on agricultural markets and GHG mitigation costs. Such an analysis was carried out by Felzer et al. (2005) and Reilly et al. (2007) for different scenarios of greenhouse gas emission and pollution controls using the MIT IGSM (Prinn et al. 1999, Reilly et al. 1999). These scenarios encompass a factorial with two pollution possibilities, policy or business-as-usual (BAU) and two greenhouse gas stabilization possibilities, policy or BAU. They include a pollution case that allows greenhouse gases (GHG) and pollutant-gas emissions to continue increasing unabated; a pollution-capped scenario that assumes no regulation of GHG emissions, but involves capping the pollutant gases everywhere at 2005 levels; a GHG stabilization scenario that assumes significant reduction in GHG emissions by 2100 equivalent to a 550 ppm stabilization; and a scenario that applies both pollution caps and GHG stabilization. 
Reilly et al. (2007) examined the effects of ozone on global yields, finding the largest effects occurred in Europe, the US, and China where ozone levels are projected to be highest. ${ }^{1}$ Modeled results for these three regions (Table 3) show decreases of crop yields from ozone exposure in 2100 of 74 to $82 \%$ for the BAU scenario, 46 to $70 \%$ with either pollution or GHG limits, and 25 to $31 \%$ with both pollution and GHG limits (Figure 2). Benefits of lower ozone occurred with GHG limits as well as with pollution limits, with the largest benefits occurring when both GHG and pollution caps were in place. Assuming a GHG stabilization policy is enacted, pollution caps in China result in $133 \%$ more yield than with no caps, as compared to $76 \%$ and $53 \%$ in the U.S. and Europe, respectively. The global economic loss associated with ozone damage to crops, pasture, and forestry was $0.8 \%$ ( $\$ 8$ trillion) of the net present value of total macroeconomic consumption between 2005 and 2100 discounted at 5\%. Net present value (NPV) benefits of avoided ozone damage associated with GHG limits were $0.3 \%$ (\$3.2 trillion) and benefits of capping pollution were $0.55 \%$ ( $\$ 5.7$ trillion) with both a pollution cap and GHG limits (Reilly et al. 2007).

Felzer et al. (2005), using the future scenarios described above, assessed the effects of reduced carbon sequestration resulting from ozone exposure on attaining a $\mathrm{CO}_{2}$ emissions target of $550 \mathrm{ppm}$ by 2100 , where the value of carbon storage was estimated as the

\footnotetext{
${ }^{1}$ Scenarios as included in Reilly et al. (2007) with additional information from the authors. Discounted at 3\% the global economic loss associated with ozone damage to crops, pasture, and forestry was $1.1 \%$ ( $\$ 24$ trillion) of the net present value of total macroeconomic consumption between 2005 and 2100. Net present value (NPV) benefits of avoided ozone damage associated with GHG limits were $0.4 \%$ ( $\$ 9.5$ trillion) and benefits of capping pollution were $0.53 \%$ ( $\$ 12$ trillion) with both a pollution cap and GHG limits (Reilly et al. 2007).
} 
avoided cost of mitigation from fossil fuels needed to achieve the same atmospheric $\mathrm{CO}_{2}$ limit. Globally, ozone reduced the accumulated carbon uptake by 2100 by $58 \mathrm{Pg} \mathrm{C}$ in the scenario without pollution caps, but only by $16 \mathrm{Pg} \mathrm{C}$ with caps. They found that reduced carbon uptake due to ozone damage would increase the NPV macroeconomic consumption cost of the GHG policy by about $0.45 \%$ ( $\$ 4.5$ trillion). The potential benefits of ozone reduction resulting from the climate policy because of the ancillary benefits on pollution emissions was about $0.5 \%$ ( $\$ 5.2$ trillion) and additional benefits of a pollution cap another $0.25 \%$ ( $\$ 2.6$ trillion). ${ }^{2}$

\section{$\underline{\text { Conclusions }}$}

Exposure to ozone causes both visible and physiological damage to vegetation. Visible injury is often a metric of ozone damage and may or may not coincide with physiological injury. Physiological injury includes reduced photosynthesis and other damage to plant functions that lead to reduced growth and biomass. A threshold response to ozone results from initial detoxification by plant antioxidants. Because most ozone enters leaves through the stomata, climatic controls on stomatal conductance regulate ozone uptake. Ozone responds to water-stress in complex ways, as lower stomatal conductance can reduce ozone uptake while ozone itself may impair stomatal function and decrease root growth. There is also contradictory evidence on how the ozone effect differs for seedlings vs. mature vegetation, with stomatal controls again playing a dominant role.

\footnotetext{
${ }^{2}$ Discounted at 3\% they found that reduced carbon uptake due to ozone damage would increase the NPV macroeconomic consumption cost of the GHG policy by about $0.51 \%$ ( $\$ 10.3$ trillion). The potential benefits of ozone reduction resulting from the climate policy because of the ancillary benefits on pollution emissions was about $0.64 \%$ ( $\$ 12.9$ trillion) and additional benefits of a pollution cap another $0.39 \%$ (\$7.8 trillion).
} 
Competitive interaction in natural environments often leads to a dominance of ozonetolerant species, reducing the diversity of the community.

Although simple regression models of the effects of ozone on vegetation have been developed, process-based models may involve ecosystem-level approaches or physiological approaches that account for diurnal variability. Various ozone metrics include simple doses, threshold indices or effective doses that account for plant detoxification, or flux-based measures that also account for stomatal conductance. Doseresponse functions rely on experimental data to relate these measures to ozone response for different species. In this sense, all models ultimately rely on empirical data to determine the sensitivity of photosynthesis or other plant functions to ozone.

Because NOx is a key part of ozone production, the coincidence of NOy deposition and surface-level ozone is a key consideration towards understanding the carbon sequestration effects on natural ecosystems. Our analysis shows that carbon sequestration resulting from $\mathrm{NOy}$ deposition can offset the negative effects of ozone exposure on temperate forests. For managed ecosystems such as croplands, however, where there is significant nitrogen fertilization, there is no compensating effect. Reducing atmospheric ozone levels will therefore not likely decrease carbon sequestration of natural forests due to compensating reductions in nitrogen deposition, but will significantly improve future crop yields and carbon sequestration in croplands or other managed ecosystems. 


\section{$\underline{\text { Acknowledgments }}$}

This study was funded by the Biocomplexity Program of the U.S. National Science Foundation (ATM-0120468), the Methods and Models for Integrated Assessment Program of the U.S. National Science Foundation (DEB-9711626) and the Earth Observing System Program of the U.S. National Aeronautics and Space Administration (NAG5-10135). We also received support from the MIT Joint Program on the Science and Policy of Global Changes. We would like to thank D. Lucas for the $\mathrm{N}$ deposition data and D. Kicklighter for their helpful reviews. 


\begin{tabular}{llll}
\hline Variable & O3 Effect & Examples of Primary Source & Frequently-Cited \\
\hline visible injury & & (Chappelka et al. 1997) & (Smith et al. 2003) \\
\hline photosynthesis & & (Reich and Amundson 1985) & (Reich 1987) \\
\hline stomatal & & (Tjoelker et al. 1995) & (Reich 1987) \\
\hline dark respiration & & (Tjoelker et al. 1995) & \\
\hline tree biomass & $\square$ & (Isebrands et al. 2001) & (Pye 1988) \\
\hline crop yield & $\square$ & (Holmes et al. 2003) & (Heck 1989) \\
\hline root growth & $\square$ & (Swank and Vose 1990) & \\
\hline decomposition & & & \\
\hline nitrogen uptake & & &
\end{tabular}




\begin{tabular}{lcccc}
\hline & USA & EU & China & Global \\
\hline Pol. & -74.5 & -79.9 & -82.5 & -64.0 \\
\hline Pol. Caps & -45.9 & -50.4 & -53.8 & -35.4 \\
\hline GHG & -57.7 & -51.2 & -70.5 & -40.0 \\
\hline Pol. Caps & -25.7 & -25.5 & -30.7 & -16.2 \\
\hline
\end{tabular}




\begin{tabular}{lllll}
\hline & Globe & China & USA & Europe \\
\hline Ozone & -73.3 & -13.0 & -18.1 & -19.8 \\
\hline NOy dep & 3.0 & 0.8 & 0.9 & 0.8 \\
\hline Lo NOy Cseq & 119.2 & 31.7 & 37.0 & 30.7 \\
\hline Hi NOy Cseq & 271.2 & 72.1 & 84.1 & 69.9 \\
\hline Total (lo) & 45.9 & 18.7 & 18.9 & 11.0 \\
\hline Total (hi) & 197.9 & 59.1 & 66.0 & 50.1 \\
\hline
\end{tabular}


Figure and Table Captions:

Table 1: Summary of ecosystem-level ozone effects. Arrows indicate ozone exposure increases (up) or decreases (down) the variable. Dark arrows indicate agreement among a wide-range of studies, while clear arrows indicate less certain results.

Table 2: Percent differences in crop yield in 2100 for difference scenarios with and

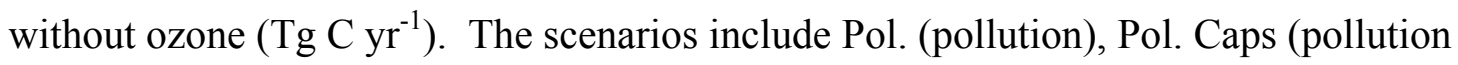
caps), GHG (greenhouse gas stabilization), and Pol. Caps + GHG (pollution caps with greenhouse gas stabilization). See text for descriptions of the scenarios.

Table 3: Carbon sequestration resulting from ozone and nitrogen deposition for temperate

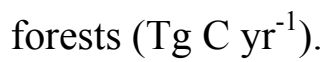

Figure 1: a) Global AOT40 concentrations of ozone (ppmhr) from MATCH and MIT IGSM models for 1980s and 1990s b) Global NOy deposition from MOZART2 model $(\mathrm{mgN} / \mathrm{m} 2)$ since pre-industrial.

Figure 2: Expected loss of crop yield due to ozone for four scenarios for a) U.S., b) Europe, c) China, and d) Globe in Tg C/yr. Scenario 1 assumes business-as-usual, Scenario 2 assumes pollution caps everywhere at 1995 levels, Scenario 3 assumes 
greenhouse gas stabilization at 550 ppm by 2100 , and Scenarios 4 assumes both pollution

caps and greenhouse gas stabilization.

\section{$\underline{\text { References }}$}

[1] R. M. Adams, S. A. Hamilton, and B. A. McCarl. The benefits of pollution control: the case of ozone and U.S. Agriculture, Amer. J. Agr. Econ. 68 (1986) 886-893.

[2] K. Aunan, T. K. Berntsen, and H. M. Seip. Surface ozone in China and its possible impact on agricultural crop yield, Ambio 29 (2000) 294-301.

[3] D. N. Barbo, A. H. Chappelka, G. L. Somers, M. S. Miller-Goodman, and K. Stolte. Diversity of an early successional plant community as influenced by ozone, New Phytologist 138 (1998) 653-662.

[4] G. A. Bartholomay, R. T. Eckert, and K. T. Smith. Reductions in tree-ring widths of white pine following ozone exposure at Acadia National Park, Maine, U.S.A., Can. J. For. Res. 24 (1997) 361-368.

[5] P. Berrang, D. F. Karnosky, and J. P. Bennett. Natural selection for ozone tolerance in Populus temuloides: field verification, Canadian Journal of Forest Research 19 (1989) 519-522.

[6] P. Berrang, D. F. Karnosky, and J. P. Bennett. Natural selection for ozone tolerance in Populus tremuloides: an evaluation of nationwide trends, Can. J. For. Res. 21 (1991) 1091-1097.

[7] P. Berrang, D. F. Karnosky, R. A. Mickler, and J. P. Bennett. Natural selection for ozone tolerance in Populus tremuloides, Can. J. For. Res. 16 (1986) 1214-1216.

[8] J. L. Beyers, G. H. Riechers, and P. J. Temple. Effects of long-term ozone exposure and drought on the photosynthetic capacity of ponderosa pine (Pinus ponderosa Laws.), New Phytologist 122 (1992) 81-90.

[9] W. L. Chameides, L. Xingsheng, T. Xiaoyan, Z. Xiuji, L. Chao, C. S. Kiang, J. St. John, R. D. Saylor, S. C. Liu, K. S. Lam, T. Wang, and F. Giorgi. Is ozone pollution affecting crop yields in China?, Geophys. Res. Lett. 26 (1999) 867-870.

[10] A. Chappelka, J. Renfro, G. Sommers, and B. Nash. Evaluation of ozone injury on foliage of black cherry (Primus serotina) and tall milkweed (Asclepias exaltata) in Great Smokey Mountains Naitonal Park, Environ. Pollut. 95 (1997) 13-18.

[11] A. H. Chappelka. Reproductive development of blackberry (Rubus cuneifolius), as influenced by ozone, New Phytologist 155 (2002) 249-255.

[12] A. H. Chappelka and L. J. Samuelson. Ambient ozone effects on forest trees of the eastern United States: a review, New Phytologist 139 (1998) 91-108.

[13] M. M. Christ, E. A. Ainsworth, R. Nelson, U. Schurr, and A. Walter. Anticipated yield loss in field-grown soybean under elevated ozone can be avoided at the expense of leaf growth during early reproductive growth stages in favourable environmental conditions, J. Exp. Bot. 57 (2006) 2267-2275. 
[14] H. Coe, M. W. Gallagher, T. W. Choularton, and C. Dore. Canopy scale measurements of stomatal and cuticular $\mathrm{O} 3$ uptake by sitka spruce, Atmos. Environ. 29 (1995) 1413-1423.

[15] J. V. H. Constable and A. L. Friend. Suitability of process-based tree growth models for addressing tree response to climate change, Environ. Pollut. 110 (2000) 47-59.

[16] D. R. Cooley and W. J. Manning. The impact of ozone on assimilate partitioning in plants: A review, Environmenal Pollution 47 (1987) 95-113.

[17] O. Dermody, S. P. Long, and E. H. DeLucia. How does elevated CO2 or ozone affect the leaf-area index of soybean when applied independently?, New Phytologist 169 (2006) 145-155.

[18] M. R. Downs, K. J. Nadelhoffer, J. M. Melillo, and J. D. Aber. Foliar and fine root nitrate reductase activity in seedlings of four forest tree species in relation to nitrogen availability, Trees: Structure and Function 7 (1993) 233-236.

[19] G. S. Edwards, S. D. Wullschleger, and J. M. Kelly. Growth and physiology of northern red oak: preliminary comparisons of mature tree and seedling responses to ozone, Environ. Pollut. 83 (1994) 215-221.

[20] B. S. Felzer, J. M. Reilly, J. Melillo, D. W. Kicklighter, M. C. Sarofim, C. Wang, R. G. Prinn, and Q. Zhuang. Future effects of ozone on carbon sequestration and climate change policy using a biogeochemistry model, Climatic Change 73 (2005) 345-373.

[21] B. S. F. Felzer, D. W. Kicklighter, J. M. Melillo, C. Wang, Q. Zhuang, and R. G. Prinn. Ozone effects on net primary production and carbon sequestration in the conterminous United States using a biogeochemistry model, Tellus 56B (2004) 230-248.

[22] E. L. Fiscus, L. B. Fitzgarrald, and K. O. BUrkey. Crop responses to ozone: uptake, modes of action, carbon assimilation and partitioning, Plant, Cell and Environment 28 (2005) 997-1011.

[23] T. S. Fredericksen, J. M. Skelly, K. C. Steiner, T. E. Kolb, and K. B. Kouterick. Size-mediated foliar response to ozone in black cherry trees, Environmenal Pollution 91 (1996) 53-63.

[24] J. Fuhrer, L. Skarby, and M. R. Ashmore. Critical levels for ozone effects on vegeation in europe, Environ. Pollut. 97 (1997) 91-106.

[25] J. W. Gregg, C. G. Jones, and T. E. Dawson. Urbanization effects on tree growth in the vicinity of New York City, Nature 424 (2003) 183-187.

[26] N. E. Grulke and P. R. Miller. Changes in gas exchange characteristics during the lifespan of giant sequoia: implications for response to current and future concentrations of atmospheric ozone, Tree Physiol. 14 (1994) 659-668.

[27] L. Grunhage, H. D. Haenel, and H. J. Jager. The exchange of ozone between vegetation and atmosphere: micrometerological measurment techniques and models, Environmenal Pollution 109 (2000) 373-392.

[28] P. J. Hanson, L. J. Samuelson, S. D. Wullschleger, T. A. Tabberer, and G. S. Edwards. Seasonal patterns of light-saturated photosynthesis and leaf conductance for mature and seedling Quercus rubra L. foliage: differential sensitivity to ozone exposure, Tree Physiol. 14 (1994) 1351-1366.

[29] A. S. Heagle. Ozone and crop yield, Annu. Rev. Phytopathol. 27 (1989) 397-423. 
[30] W. W. Heck, Assessment of crop losses from air pollutants in the United States. in: J. J. MacKenzie and M. T. El-Ashry (Ed.), Air Pollution's Toll on Forests and Crops, Yale University Press, New Haven, 1989, pp. 235-315.

[31] W. W. Heck, W. W. Cure, J. O. Rawlings, L. J. Zaragoza, A. S. Heagle, H. E. Heggestad, R. J. Kohut, L. W. Kress, and P. J. Temple. Assessing impacts of ozone on agricultural crops: I. overview, J. Air Pollut. Control Assoc. 34 (1984a) 729-735.

[32] W. W. Heck, W. W. Cure, J. O. Rawlings, L. J. Zaragoza, A. S. Heagle, H. E. Heggestad, R. J. Kohut, L. W. Kress, and P. J. Temple. Assessing impacts of ozone on agricultural crops: II. crop yield functions and alternative exposure statistics, J. Air Pollut. Control Assoc. 34 (1984b).

[33] W. W. Heck and C. S. Furiness. The effects of ozone on ecological systems: time for a full assessment, $\operatorname{EM(2001)~15-24.~}$

[34] W. E. Holmes, D. R. Zak, K. S. Pregitzer, and J. S. King. Soil nitrogen transformations under Populis termuloides, Betula papyrifera and Acer saccharum following 3 years exposure to elevated CO2 and O3, Glob. Change Biol. 9 (2003) 1743-1750.

[35] IPCC, (Ed). Climate Change 2001: The Scientific Basis. Cambridge University Press, New York, 2001, 881.

[36] J. G. Isebrands, E. P. McDonald, E. Kruger, G. Hendrey, K. Percy, K. Pregitzer, J. Sober, and D. F. Karnosky. Growth responses of Populus tremuloides clones to interacting elevated carbon dioxide and tropospheric ozone, Environ. Pollut. 115 (2001) 359-371.

[37] K. F. Jensen and B. R. Roberts. Changes in yellow poplar stomatal resistance in SO2 and O3 fumigation, Environmenal Pollution 41 (1986) 235-245.

[38] D. F. Karnosky, K. S. Pregitzer, D. R. Zak, M. E. Kubiske, G. R. Hendrey, D. Weinstein, M. Nosal, and K. E. Percy. Scaling ozone responses of forest trees to the ecosystem level in a changing climate, Plant Cell Environ. 28 (2005) 965-981.

[39] D. F. Karnosky and K. C. Steiner. Provenance and family variation in response of Fraxinus americana and F. pennsylvanica to ozone and sulfur dioxide, Phytopathology 71 (1981) 804-807.

[40] D. F. Karnosky, D. R. Zak, K. S. Pregitzer, C. S. Awmack, J. G. Bockheim, R. E. Dickson, G. Hendrey, R., G. E. Host, J. S. King, B. J. Kopper, E. L. Kruger, M. E.

[41] Kubiske, R. L. Lindroth, W. J. Mattson, E. P. McDonald, A. Noormets, E. Oksanen, W. F. J. Parsons, K. E. Percy, G. K. Podila, D. E. Riemenschneider, P. Sharma, R. Thakur, A. Sober, J. Sober, W. S. Jones, S. Anttonen, E. Vapaavuori, B. Mankovska, W. Heilman, and J. G. Isebrands. Tropospheric O3 moderates responses of temperate hardwood forests to elevated $\mathrm{CO} 2$ : $\mathrm{s}$ synthesis of molecular to ecosystem results from the Aspen FACE project, Functional Ecology 17 (2003) 289-304.

[42] J. S. Kim, A. H. Chappelka, and M. S. Miller-Goodman. Decomposition of blackberry and broomsedge bluestem as influenced by ozone, Journal of Environmental Quality 27 (1998) 953-960.

[43] S. V. Krupa and W. J. Manning. Atmospheric ozone: formation and effects on vegetation, Environ. Pollut. 50 (1988). 
[44] J. F. Lamarque, J. T. Kiehl, G. P. Brasseur, T. Butler, P. Cameron-Smith, W. D. Collins, W. J. Collins, C. Granier, D. Hauglustaine, P. G. Hess, E. A. Holland, L. Horowitz, M. G. Lawrence, D. McKenna, P. Merilees, M. J. Prather, P. J. Rasch, D. Rotman, D. Shindell, and P. Thornton. Assessing future nitrogen deposition and carbon cycle feedback using a multimodel approach: Analysis of nitrogen deposition, J. Geophys. Res. 110 (2005) 21.

[45] J. A. Laurence, W. A. Retzlaff, J. S. Kern, E. H. Lee, W. E. Hogsett, and D. A. Weinstein. Predicting the regional impact of ozone and precipitation on the growth of loblolly pine and yellow-poplar using linked TREGRO and ZELIG models, Forest Ecol. Manag. 146 (2001) 247-263.

[46] A. D. B. Leakey, M. Uribelarrea, E. A. Ainsworth, S. L. Naidu, A. Rogers, D. R. Ort, and S. P. Long. Photosynthesis, productivity, and yield of maize are not affected by open-air elevation of $\mathrm{CO} 2$ concentration in the absense of drought, Plant Physiology 140 (2006) 779-790.

[47] A. S. Lefohn, S. J. Oltmans, T. Dann, and H. B. Singh. Present-day variability of background ozone in the lower troposphere, J. Geophys. Res. 106 (2001) 99459958.

[48] R. L. Lindroth, B. J. Kopper, W. F. J. Parsons, J. G. Bockheim, D. F. Karnosky, G. R. Hendrey, K. S. Pregitzer, J. G. Isebrands, and J. Sober. Consequences of elevated carbon dioxide and ozone for foliar chemical composition and dynamics in trembling aspent (Populus tremuloides) and paper birch (Betual papyrifera), Environ. Pollut. 115 (2001) 395-404.

[49] S. P. Long, E. A. Ainsworth, A. D. B. Leakey, and P. B. Morgan. Global food insecurity. Treatment of major food crops with elevated carbon dioxide or ozone under large-scale fully open-air conditions suggests recent models may have overestimated future yields, Phil. Trans. R. Soc. Lond. 360 (2005) 2011-2020.

[50] S. P. Long, E. A. Ainsworth, A. D. B. Leakey, J. Nosberger, and D. R. Ort. Food for thought: lower-than-expected crop yield stimulation with rising $\mathrm{CO} 2$ concentrations, Science 312 (2006) 1918-1921.

[51] T. M. Lyons, J. D. Barnes, and A. W. Davison. Relationships between ozone resistance and climate in European populations of Plantago major, New Phytologist 136 (1997) 503-510.

[52] J. J. MacKenzie and M. T. El-Ashry, editors. Air Pollution's Toll on Forests and Crops. Yale University Press, New Haven, 1989, 376.

[53] A. H. Magill, J. D. Aber, G. M. Berntson, W. H. McDowell, K. J. Nadelhoffer, J. M. Melillo, and P. A. Steudler. Long-term nitrogen additions and nitrogen saturation in two temperate forests, Ecosystems 3 (2000) 238-253.

[54] A. H. Magill, J. D. Aber, W. S. Currie, K. J. Nadelhoffer, M. E. Martin, W. H. McDowell, J. M. Melillo, and P. A. Steudler. Ecosystem response to 15 years of chronic nitrogen additions at the Harvard Forest LTER, Massachusetts, USA, Forest Ecol. Manag. 196 (2004) 7-28.

[55] T. A. Mansfield, M. Person, C. J. Atkinson, and P. A. Wookey, Ozone, sulphur dioxide and nitrogen oxides: some effect on the water relations of herbaceous plants and trees.. in: M. B. Jackson and C. R. Black (Ed.), Interacting Stresses on Plants in a Changing Climate, Springer Verlag, Berline, 1993, pp. 77-88. 
[56] M. J. Martin, G. E. Host, K. E. Lenz, and J. G. Isebrands. Simulating the growth response of aspen to elevated ozone: a mechanistic approach to scaling a leaflevel model of ozone effects on photosynthesis to a complex canopy architecture, Environ. Pollut. 115 (2001) 425-436.

[57] W. J. Massman. Toward an ozone standard to protect vegetation based on effective dose: a review of deposition resistances and a possible metric, Atmos. Environ. 38 (2004) 2323-2337.

[58] D. L. Mauzerall and X. Wang. Protecting agricultural crops from the effects of tropospheric ozone exposure: reconciling science and standard setting in the United States, Europe, and Asia, Annu. Rev. Energy Enivron. 26 (2001).

[59] S. B. McLaughlin and D. J. Downing. Interactive effects of ambient ozone and climate measured on growth of mature forest trees, Nature 374 (1995) 252-254.

[60] S. B. McLaughlin and D. J. Downing. Interactive effects of ambient ozone and climate measured on growth of mature forest trees, Can. J. For. Res. 26 (1996) 670-681.

[61] F. C. Meinzer and D. A. Grantz. Coordination of stomatal, hydraulic, and canopy boundary layer properties: do stomata balance conductances by measuring transpiration?, Physiol. Plantarum 83 (1991) 324-329.

[62] J. M. Melillo and J. R. Gosz, Interactions of biogeochemical cycles in forest ecosystems. in: R. B. Cook (Ed.). The Major Biogeochemical Cycles and Their Interactions, John Wiley and Sons, New York, 1983,

[63] J. M. Melillo and P. A. Steudler. The effect of nitrogen fertilization on the COS and CS2 emissions from temperate forest soils, J. Atmos. Chem. 9 (1989) 411-417.

[64] J. M. Melillo, P. A. Steudler, J. D. Aber, K. Newkirk, H. Lux, F. P. Bowles, C. Catricala, A. Magill, T. Ahrens, and S. Morrisseau. Soil warming and carboncycle feedbacks to the climate system, Science 298 (2002) 2173-2176.

[65] P. B. Morgan, T. A. Mies, G. A. Bollero, R. L. Nelson, and S. P. Long. Season-long elevation of ozone concentration to projected 2050 levels under fully open-air conditions substantially decreases the growth and production of soybean, New Phytologist 170 (2006) 333-343.

[66] R. B. Muntifering, D. D. Crosby, M. C. Powell, and A. H. Chappelka. Yield and quality characteristics of bahiagrass (Paspalum notatum) exposed to ground-level ozone, Anim. Feed Sci. Tech. 84 (2000) 243-256.

[67] R. C. Musselman and W. J. Massman. Ozone flux to vegetation and its relationship to plant response and ambient air quality standards, Atmos. Environ. 33 (1999) 65-73.

[68] K. J. Nadelhoffer, B. A. Emmett, P. Gundersen, O. J. Kjonaas, C. J. Koopmans, P. Schleppi, A. Tietema, and R. F. Wright. Nitrogen deposition makes a minor contribution to carbon sequestration in temperate forests, Nature 398 (1999) 145148.

[69] A. Noormets, A. Sober, E. J. Pell, R. E. Dickson, G. K. Podila, J. Sober, J. G. Isebrands, and D. F. Karnosky. Stomatal and non-stomatal limitation to photosynthesis in two trembling aspen (Populus tremuloides Michx.) clones exposed to elevated $\mathrm{CO}_{2}$ and/or $\mathrm{O}_{3}$, Plant, Cell and Environment 24 (2001) 327336. 
[70] S. V. Ollinger, J. D. Aber, and P. B. Reich. Simulating ozone effects on forest productivity: interactions among leaf-, canopy-, and stand-level processes, Ecol. Appl. 7 (1997) 1237-1251.

[71] S. V. Ollinger, J. D. Aber, P. B. Reich, and R. J. Freuder. Interactive effects of nitrogen deposition, tropospheric ozone, elevated $\mathrm{CO}_{2}$ and land use history on the carbon dynamics of northern hardwood forests, Glob. Change Biol. 8 (2002) 545562.

[72] S. J. Oltmans and H. Levy II. Surface ozone measurements from a global network, Atmos. Environ. 28 (1994) 9-24.

[73] E. J. Pell, J. P. Sinn, N. Eckardt, C. Vinten Johansen, W. E. Winner, and H. A. Mooney. Response of radish to multiple stresses II. influence of season and genotype on plant response to ozone and soil moisture deficit, New Phytologist 123 (1993) 153-163.

[74] E. J. Pell, W. E. Winner, C. Vinten Johansen, and H. A. Mooney. Response of radish to multiple stresses I. physiological and growth responses to changes in ozone and nitrogen, New Phytologist 115 (1990) 439-446.

[75] K. Percy, M. Nosal, W. Heilman, T. Dann, J. Sober, and D. Karnosky. The North American ozone air quality standard: efficacy and performance with two northern hardwood forest tree species, Letzte Aktualisierung(2006).

[76] K. E. Percy, A. H. Legge, and S. V. Krupa, Troposphere ozone: a continuing threat to global forests?. in: D. F. e. a. Karnosky (Ed.). Air Pollution, Global Change and Forests in the New Millenium, Elsevier Ltd., 2003, pp. 85-118.

[77] K. E. Percy, M. Nosal, W. Heilman, T. Dann, J. Sober, A. H. Legge, and D. F. Karnosky. New exposure-based metric approach for evaluating O3 risk to North American aspen forests, Environ. Pollut. 147 (2007) 554-566.

[78] H. Pleijel, H. Danielsson, K. Ojanpera, L. D. Temmerman, P. Hogy, M. Badiani, and P. E. Karlsson. Relationships between ozone exposure and yield loss in European wheat and potato - a comparison of concentration - and flux-based exposure indices, Atmos. Environ. 38 (2004) 2259-2269.

[79] M. C. Powell, R. B. Muntifering, J. C. Lin, and A. H. Chappelka. Yield and nutritive quality of sericea lespedeza (Lespedeza cuneata) and little bluestem (Schizachyrium scoparium) exposed to ground-level ozone, Environ. Pollut. 122 (2003) 313-322.

[80] R. Prinn, H. Jacoby, A. Sokolov, C. Wang, X. Xiao, Z. Yang, R. Eckhaus, P. Stone, D. Ellerman, J. M. Melillo, J. Fitzmaurice, D. W. Kicklighter, G. Holian, and Y. Liu. Integrated global system model for climate policy assessment: feedbacks and sensitivity studies, Climatic Change 41 (1999) 469-546.

[81] J. M. Pye. Impact of ozone on the growth and yield of tress: a review, Journal of Environmental Quality 17 (1988) 347-360.

[82] J. Rebbeck and K. F. Jensen. Ozone effects on grafted mature and juvenile red spruce: photosynthesis, stomatal conductance, and chlorophyll concentration, Can. J. For. Res. 23 (1993) 450-456.

[83] P. B. Reich. Quantifying plant response to ozone: a unifying theory, Tree Physiol. 3 (1987) 63-91.

[84] P. B. Reich and R. G. Amundson. Ambient levels of ozone reduce net photosynthesis in tree and crop species, Science 230 (1985) 566-570. 
[85] J. Reilly, S. Paltsev, B. Felzer, X. Wang, D. Kicklighter, J. Melillo, R. Prinn, M. Sarofim, A. Sokolov, and C. Wang. Global economic effects of changes in crops, pasture, and forests due to changing climate, carbon dioxide, and ozone, Energ. Policy(2007) in press.

[86] J. Reilly, R. Prinn, J. Harnisch, J. Fitzmaurice, H. Jacoby, D. W. Kicklighter, J. M. Melillo, P. Stone, A. Sokolov, and C. Wang. Multi-gas assessment of the Kyoto Protocol, Nature 401 (1999) 549-555.

[87] V. C. Runeckles and B. I. Chevone, Tree responses to ozone. in: A. S. Lefohn (Ed.). Surface-level ozone exposures and their effects on vegetation, Lewis Publishers Inc., Chelsea, MI, USA, 1992, pp. 189-270.

[88] V. C. Runeckles and K. Palmer. Pretreatment with nitrogen dioxide modifies plant response to ozone, Atmos. Environ. 21 (1987) 717-719.

[89] L. J. Samuelson and G. S. Edwards. A comparison of sensitivity to ozone in seedlings and trees of Quercus rubra L., New Phytologist 125 (1993) 373-379.

[90] L. J. Samuelson and J. M. Kelly. Carbon partitioning and allocation in norther red oak seedlings and mature trees in response to ozone, Tree Physiol. 16 (1996) 853858.

[91] L. J. Samuelson, J. M. Kelly, P. A. Mays, and G. S. Edwards. Growth and nutrition of Quercus rubra L. seedlings and mature trees after three seasons of ozone exposure, Environmenal Pollution 91 (1996) 317-323.

[92] W. H. Schlesinger, Biogeochemistry: an analysis of global change, Academic Press, Inc., New York, 1991, 443.

[93] J. H. Seinfeld. Urban air pollution: state of the science, Science 243 (1989) 745-752.

[94] R. E. Showman. A comparison of ozone injury in vegetation during moist and drought years, J. Air Waste Manag. Assoc. 41 (1991) 63-64.

[95] H. B. Singh, F. L. Ludwig, and W. B. Johnson. Tropospheric ozone: concentrations and variabilities in clea remote atmospheres, Atmos. Environ. 12 (1978) 21852196.

[96] G. Smith, J. Coulston, E. Jepsen, and T. Prichard. A national ozone biomonitoring program - results from field surveys of ozone sensitive plants in northeastern forests (1994-2000), Environ. Monit. Assess. 87 (2003) 271-291.

[97] G. L. Somers, A. H. Chappelka, P. Rosseau, and J. R. Renfro. Empirical evidence of growth decline related to visible ozone injury, Forest Ecol. Manag. 104 (1998) 129-137.

[98] C. L. Spash. Assessing the economic benefits to agriculture from air pollution control, Journal of Economic Surveys 11 (1997) 47-70.

[99] W. T. Swank and J. M. Vose. Watershed-scale response to ozone events in a pinus strobus L. plantation, Water Air Soil Poll. 54 (1990) 119-133.

[100] J. Taylor, G. E., D. W. Johnson, and C. P. Andersen. Air pollution and forest ecosystems: a regional to global perspective, Ecol. Appl. 4 (1994) 662-689.

[101] R. O. Teskey, Synthesis and conclusions from studies of southern commercial pines. in: S. Fox and R. A. Mickler (Ed.), Impacts of Air Pollutants on Southern Pine Forests, Ecological Studies, Springer-Verlag, New York, NY, 1996, pp. 467490. 
[102] M. G. Tjoelker, J. C. Volin, J. Oleksyn, and P. B. Reich. Interaction of ozone pollution and light effects on photosynthesis in a forest canopy experiment, Plant, Cell and Environment 18 (1995) 895-905.

[103] M. Treshow and D. Stewart. Ozone sensitivity of plants in natural communities, Biol. Conserv. 5 (1973) 209-214.

[104] X. Wang and D. L. Mauzerall. Characterizing distributions of surface ozone and its impact on grain production in China, Japan and South Korea: 1990 and 2020, Atmos. Environ. 38 (2004) 4383-4402.

[105] D. A. Weinstein, L. J. Samuelson, and M. A. Arthur. Comparison of the response of red oak (Quercus rubra) seedlings and mature trees to ozone exposure using simulation modeling, Environ. Pollut. 102 (1998) 307-320.

[106] D. A. Westenbarger and G. B. Frisvold. Air pollution and farm level crop yields: an empirical analysis of corn and soybeans, Agr. Resources Econ. Rev. 24 (1995) 156-165.

[107] S. C. Yun, E. W. Park, and J. A. Laurence. Simulation of 1-year-old Populus tremuloides response to ozone stress at Ithaca, USA, and Suwon, Republic of Korea, Environ. Pollut. 112 (2001) 253-260.

[108] Y. Zheng, K. J. Stevenson, R. Barrowcliffe, S. Chen, H. Wang, and J. D. Barnes. Ozone levels in Chongqing: a potential threat to crop plants commonly grown in the region?, Environ. Pollut. 99 (1998) 299-308. 
JJA AOT4O

1980s, 1990s
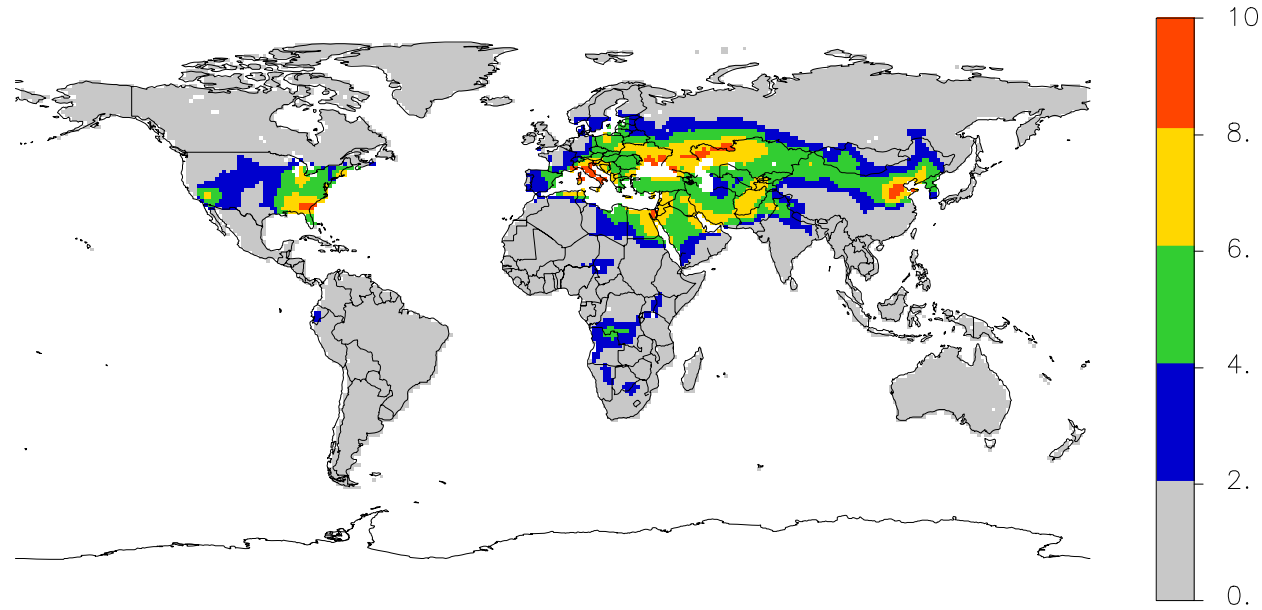

Figure 1a

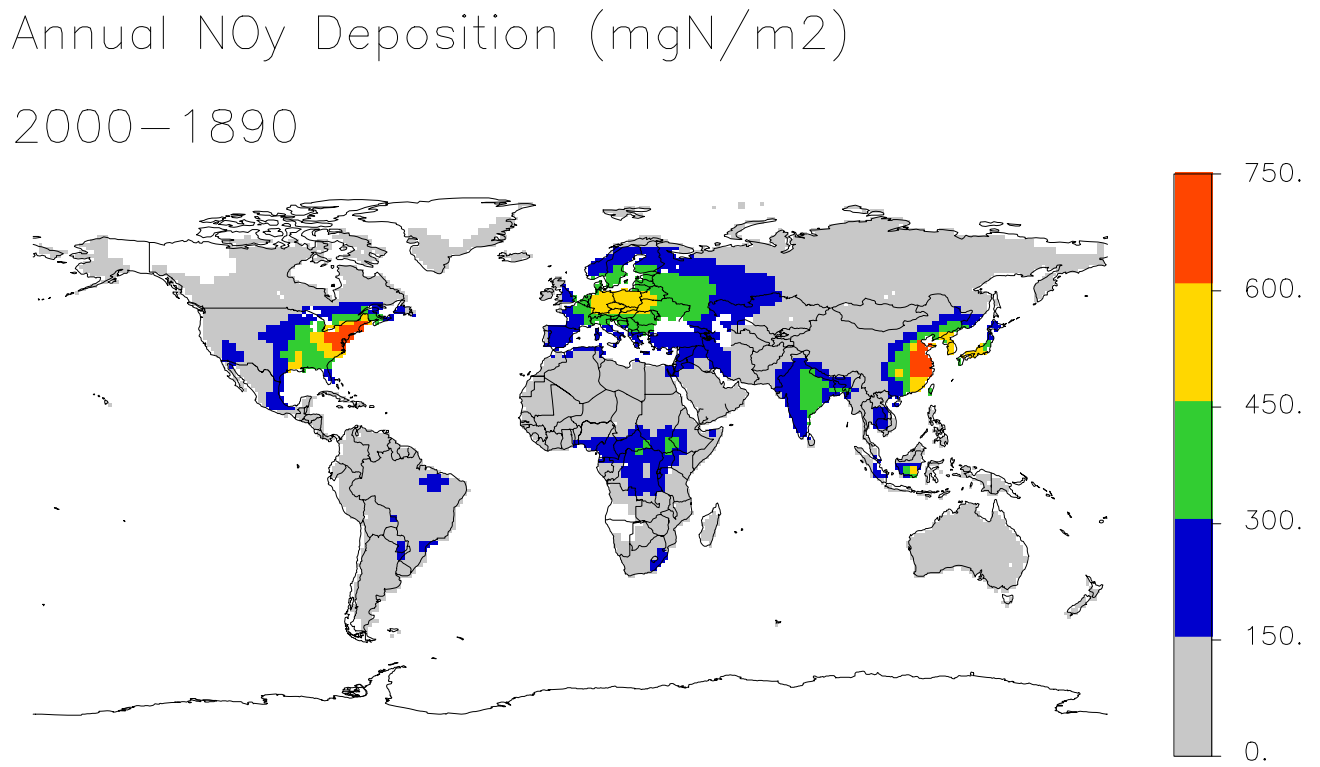

Figure $1 b$ 


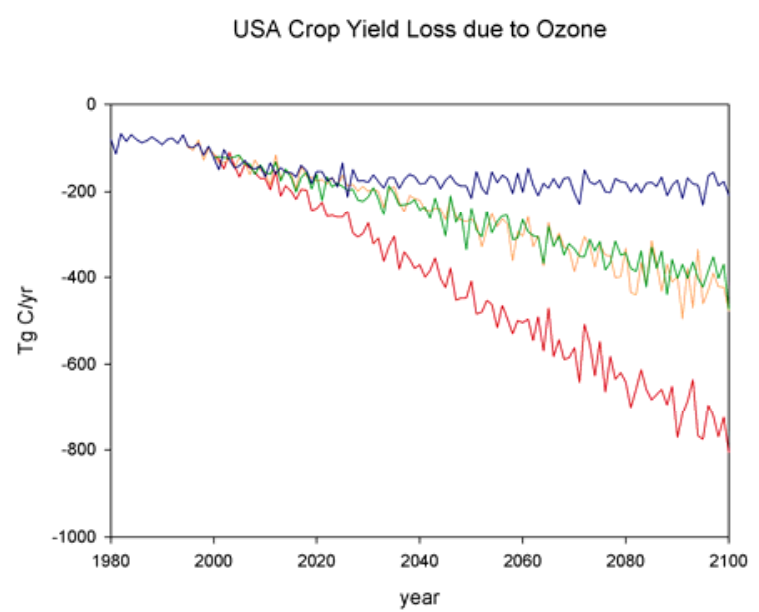

Figure 2a

Europe Crop Yield Loss due to Ozone

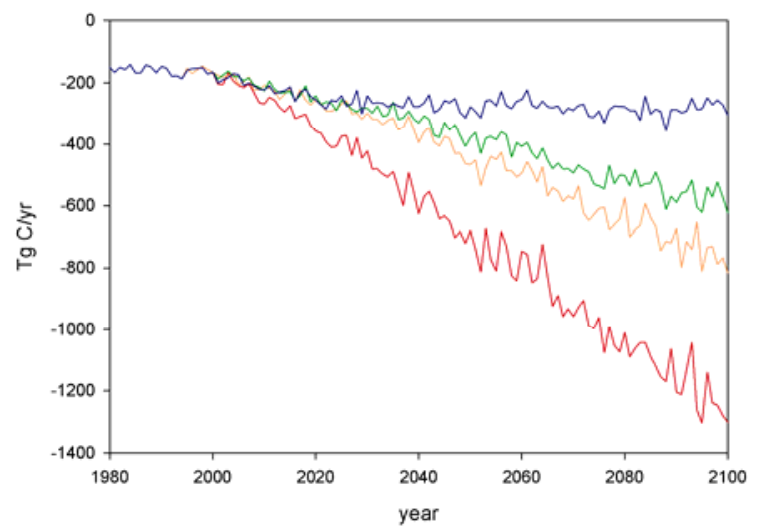

Figure $2 b$

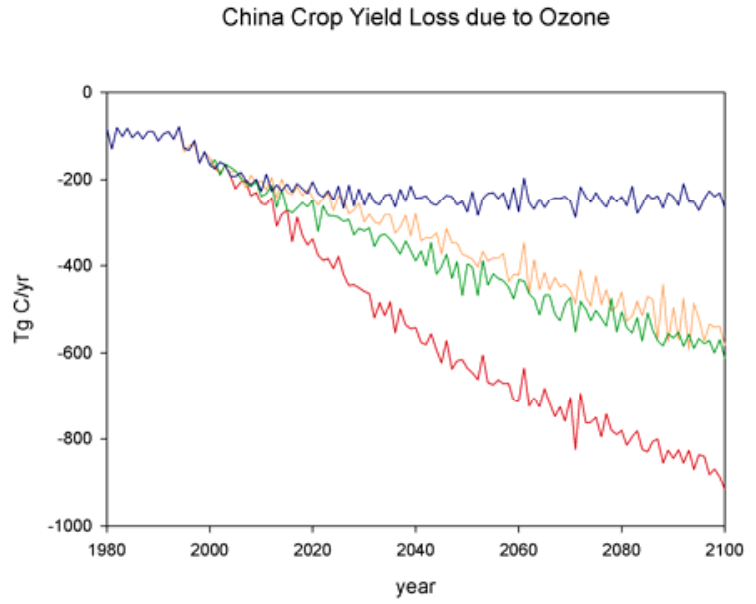

Figure 2c 
Globe Crop Yield Loss due to Ozone

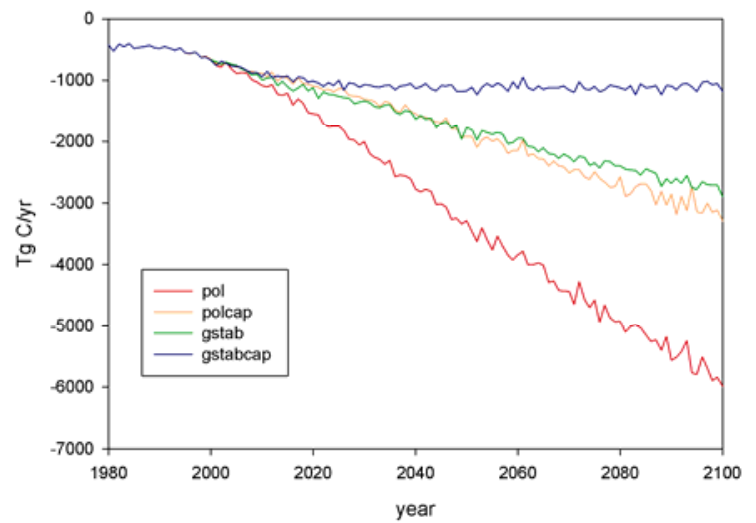

Figure $2 d$ 